\title{
KINERJA APARAT DINAS SOSIAL DALAM MELAKUKAN PEMBINAAN PENGEMIS DI KOTA GORONTALO
}

\author{
Arif Gani $^{1}$, Zulaecha Ngiu ${ }^{2}$, Maisara Sunge ${ }^{3}$ \\ Fakultas Ilmu social, Universitas Negeri Gorontalo \\ (arifgani@gmail.com) \\ (zulaechangiu@gmail.com) \\ (maisarasunge@gmail.com)
}

\begin{tabular}{l} 
Info Artikel \\
\hline Sejarah Artikel: \\
Diterima (Mei) (2021) \\
Disetujui (juni) (2021) \\
Dipublikasikan (Juli) \\
(2021) \\
\hline Keywords: \\
Aparat Dinas Sosial \\
Kinerja \\
Pembinaan Pengemis \\
\hline
\end{tabular}

Abstrak

Penelitian ini bertujuan untuk mengetaui kinerja aparat dinas sosial dalam melakukan pembinaan pengemis di kota gorontalo dan mengetahui faktor-faktor yang menjadi penghambat dari dinas sosial dalam melakukan pembinaan pengemis di kota gorontalo. Metode yang digunakan dalam penelitian ini metode kualitatif deskriptif. Dengan demikian peneliti berperan sebagai instrument utama yang terlibat secara langsung dalam mengumpulkan data melalui teknik observasi, teknik wawancara dan teknin dokumentasi. Hasil penelitian ini teradapat empat faktor yang menjadi penghambat kinerja aparat dinas sosial dalam melakukan pembinaan pengemis yaitu : faktor ekonomi, panti rehabilitasi, regulasi dankerja sama dengan instansi terkait. Selama ini program pembinaan pengemis yang dilakukan oleh aparat dinas sosial dituangkan dalam bentuk bimbingan dan pelatihan. Bimbingan dan Pelatihan yang dimaksud adalah : 1) bimbingan mental, 2) bimbingan kesehatan, 3) bimbingan ketertiban, 4) bimbingan keagamaan dan bentuk pelatihan yang dilakukan menyetir dan menjahit. Hasil penelitian secara keseluruhan terlihat selama ini kinerja aparat dinas sosial dalam melakukan pembinaan pengemis di kota gorontalo sudah cukup baik. hanya saja ada beberapa poin yang menjadi Penghambat dari Aparat Dinas Sosial dalam Melakukan Pembinaan Pengemis Di Kota Gorontalo seperti Panti Rehabilitasi dan Regulasi yang harus menjadi perhatian khusus dari Pemprov Gorontalo sehingga program pembinaan pengemis akan lebih baik lagi dan berjalan dengan efektif.

\footnotetext{
${ }^{1}$ Mahasiswa Universitas Negeri Gorontalo

${ }^{2}$ Dosen Universitas Negeri Gorontalo

${ }^{3}$ Dosen Universitas Negeri Gorontalo
} 


\section{PENDAHULUAN}

Indonesia merupakan salah satu negara yang mempunyai penduduk yang sangat banyak maka perlu peningkatan pembangunan untuk menopang kesejahteraan penduduknya. Sebagaimana yang telah dijelaskan bahwa pembangunan nasional adalah usaha peningkatan kualitas manusia dan masyarakat Indonesia secara berkelanjutan dengan memanfaatkan kemajuan ilmu pengetahuan dan teknologi serta memperhatikan tantangan perkembangan global. Selain itu, tujuan pembangunan nasional untuk mewujudkan masyarakat adil dan makmur yang merata material dan spiritual, serta menjalankan roda perekonomian guna mewujudkan kesejahteraan sosial. Sesuai dengan pasal 33 UUD 1945 ialah sebagai dasar negara untuk mewujudkan keadilan, kesejahteraan dan kemakmuran rakyat melalui peranan dan keberpihakan negara dalam meningkatkan taraf hidup rakyat.

Tujuan pembangunan nasional dan pasal 33 UUD 1945 tersebut akan tercapai atau dapat berjalan dengan baik apabila pemerintah dan masyarakat saling membantu dalam proses pembangunan termasuk dibidang kesejahteraan sosial. Melihat pada zaman sekarang ini masih banyak sebagian masyarakat hidup dalam keterbatasan dilingkaran kemiskinan sebagai penyebab utama munculnya para pengemis yang hidup dijalanan yang kehidupannya sangat memerlukan bantuan dari pemerintah agar mereka dapat merasakan kehidupan yang normal. Hal ini sangat memerlukan kebijakan dan program dari pemerintah untuk membantu masyarakat khususnya para pengemis dalam mengatasi masalah sosialnya.

Setiap daerah di Indonesia, pasti kita bisa jumpai kelompok-kelompok pemalas yang dikenal dengan pengemis tersebut. Tak terkecuali di Kota Gorontalo. Hal ini membuat sebagian masyarakat kota Gorontalo yang mengeluhkan banyaknya aktivitas pengemis khususnya pada malam hari. Pengemis di Kota Gorontalo memang belum separah di kota-kota lain. namun, untuk jumlah bukan hal yang dipandang sebelah mata. Bukan hanya untuk pengemis yang cacat fisik namun yang kelihatannya masih kuat dan sehat pun sudah melakukan aktivitas mengemis seperti yang ada di pinggiran jalan maupun pusat perbelanjaan di Kota Gorontalo.

Berdasarkan hasil observasi awal, Data yang peneliti dapatkan dari kantor Dinas Sosial diketahui bahwa jumlah pengemis yang ada di Kota Gorontalo pada tahun 2018 berjumlah 15 orang yang terdiri dari laki-laki dan perempuan, mereka berasal dari 
kelurahan dan kecamatan yang berbeda dan beberapa dari mereka tinggal di lingkungan yang sama. Rata-rata jenis permasalahan yang mereka alami oleh para pengemis sama yaitu karena faktor ekonomi.

Dengan demikian, maka penelitian ini bertujuan untuk mengetahui kinerja aparat dinas sosial dan faktor apa saja yang menjadi penghambat dari aparat dinas sosial dalam melakukan pembinaan pengemis di kota Gorontalo.

\section{METODE PENELITIAN}

Penulis menggunakan jenis penelitian kualitatif deskriptif dimana mencoba menggambarkan tentang sifat-sifat individu, keadaan, gejala-gejala dalam kelompok tertentu, menetukan adanya hubungan tertentu antara satu gejala dengan gejala yang lainnya dalam masyarakat. Menurut Sugiyono (2013:53) metode penelitian pada dasarnya merupakan cara ilmiah untuk mendapatkan data dengan tujuan dan kegunaan tertentu. Dengan upaya mendapatkan dan mengumpulakan data dari kegiatan penelitian.

\section{HASIL PENELITIAN}

\section{A. Kinerja Aparat Dinas Sosial dalam melakukan pembinaan pengemis di Kota Gorontalo}

Permasalahan sosial pengemis merupakan akumulasi dan interaksi dari berbagai permasalahan seperti halnya kemiskinan, rendah pendidikan, minimnya keterampilan kerja, lingkungan, sosial budaya dan lain-lain. Masalah ini merupakan masalah sosial dan bersifat sebagai penyakit dalam masyarakat. Maka dari itu perlu adanya perhatian dari Dinas Sosial yang merupakan unsur pelaksana dari pemeritah untuk segera menangangi masalah tersebut agar masyarakat tak lagi resah dengan munculnya para pengemis dilingkungan mereka. Ada 4 indikator kinerja untuk mengukur program pembinaan yang dilakukan oleh aparat dinas sosial yaitu:

a. Efektivitas kinerja

Menurut Efendy efektivitas adalah komunikasi yang prosesnya mencapai tujuan yang direncanakan sesuai dengan biaya yang dianggarkan, waktu yang ditetapkan dan jumlah personil yang ditentukan. (e-journal.uajy.ac.id). Berdasarkan teori diatas bahwa 
efektivitas kinerja yang dimaksud terbagi menjadi indikator yaitu: 1) Anggaran, 2) Waktu, dan 3) Sumber daya manusia. Ketiga indikator tersebut akan peneliti bahas secara rinci per indikator berdasarkan hasil penelitian yang peneliti dapatkan dilapangan.

Berdasarkan hasil penelitian mengenai anggaran maka peneliti dapat menjelaskan bahwa dalam melakukan program pembinaan pengemis aparat dari Dinas Sosial mendapatkan anggaran dari APBD dan APBN dan Anggaran tersebut pun sudah diberikan kepada pengemis yang masuk kategori penyandang disabilitas, hasil wawancara mengenai waktu pelakasanaan pembinaan pengemis tersebut peneliti dapat memberikan kesimpulan bahwa aparat dinas sosial Kota Gorontalo melakukan pembinaan pengemis setahun sekali kecuali di tahun 2019 karena jumlah pengemis yang cukup banyak dan harus dilakukan pembinaan dua kali. Kemudian hasil Dari wawancara bersama Sekretaris Satpol PP diatas, peneliti dapat memberikan kesimpulan bahwa dalam hal kerja sama antara Dinas Sosial dan Satpol PP Kota Gorontalo itu sudah pasti ada sesuai dengan Perda yang. Namun, semua hanya tergantung bagimana komunikasi yang dijalin antara Pihak Dinas Sosial dengan Satpol PP.

\section{b. Efisiensi Kinerja}

Menurut Mulyadi (2007:63) efisiensi adalah tepat atau sesaui untuk mengerjakan (menghasilkan) sesuatu dengan tidak membuang-buang waktu, tenaga dan biaya. Efisiensi yang dimaksud disini ialah bagaimana melakukan proses pembinaan terhadap para pengemis harus tepat atau sesuai sasaran untuk menghasilkan sesuatu atau mengelurkan potensi yang ada pada diri mereka dengan tidak membuang-buang waktu, tenaga maupun biaya. Berdasarkan hasil wawancara mengenai Efisiensi kinerja yang peneliti temui dapat disimpulkan bahwa proses pembinaan yang dilakukan oleh pihak dinas sosial disini itu lebih mengarah kepada bagimana pihak dinas sosial menggali potensi-potensi yang ada pada diri mereka (pengemis), kemudian setelah itu para pengemis diberikan pelatihan-pelatihan keterampilan seperti pelatihan menjahit dan mengemudi agar nantinya ketika mereka kembali ke dalam lingkungan masyarakat bisa menyesuaikan diri. Namun dalam hal ini sebelum mereka melakukan pelatihan-pelatihan, mereka terlebih dahulu harus melalui proses-proses bimbingan khusus dari pihak dinas sosial seperti, bimbingan mental, kesehatan, ketertiban, maupun keagamaan. Dan pihak dinas sosial telah berupaya 
melakukan kegiatan ini dengan terlibat langsung selama proses pembimbingan tersebut.

c. Keadilan

Menurut John Rawl dalam Khoiron (2017:12) Keadilan adalah harus memberikan kesempatan yang kepada seluruh warganya, atau setiap individu mempunyai posisi yang sama, setara dalam potensi dan kesempatan. Keadilan yang dimaksud disini adalah aparat dinas sosial harus memberikan kesempatan yang sama kepada seluruh pengemis, atau setiap individu mempunyai posisi yang sama, setara dalam potensi dan kesempatan. Berdasarkan hasil wawancara dari beberapa informan mengenai keadilan kinerja dari aparat dinas sosial, peneliti dapat mengambil sebuah kesimpulan bahwa pihak dinas sosial sudah melakukan pelayanan secara adil tanpa membeda-bedakan dari mana pengemis itu berasal. Namun, dalam hal ini masih ada saja pengemis yang mengaku belum pernah dapat bantuan maupun pembinaan dari pihak dinas sosial agar dapat simpati dari masyarakat walaupun dari pihak dinas sosial telah memberikan bantuan dan telah melakukan program pembinan kepada mereka.

\section{d. Daya Tanggap}

Menurut Kumorotomo dalam Pasolong (2010:180) Daya tanggap organisasi pelayanan publik merupakan bagian dari daya tanggap Negara atau pemerintah akan kebutuhan masyarakat yang mendesak. Daya tanggap yang dimaksud disini adalah bagimana daya tanggap organsisasi pelayanan publik khususya dinas sosial meberikan respon terhadap kebutuhan dari para pengemis. Berdasarkan hasil wawancara mengentai daya tanggap kinerja peneliti dapat memberikan kesimpulan bahwa ketika aparat dinas sosial mendapatkan informasi tetang keluhan-keluhan dari para pengemis, mereka langsung turun kelokasi dimana tempat mereka mengemis untuk mencari tau apa keluhan dari para pengemis. Hasilnya yaitu para pengemis menginginkan bantuan dari dinas sosial namun ada sebagian pengemis yang tidak masuk dalam kategori penyendang disabilitas. Sementara bantuan yang di programkan oleh pihak dinas sosial dikhususkan bagi para penyandang disabiltas.

\section{B. Faktor Penghambat Dari Aparat Dinas Sosial Dalam Melakukan Pembinaan Pengemis Di Kota Gorontalo}

Ada bebrapa faktor yang menjadi penghambat dari dinas sosial dalam melakukan pembiaan pengemis diantaranya adalah :

a. Faktor Ekonomi 
Manusia pada dasarnya mempunyai kebutuhan yang tidak terbatas dan saat itulah mereka dihadapkan oleh permasalahan ekonomi untuk memenuhi suatu kebutuhan masing-masing. Ekonomi menjadi salah satu faktor yang mempengaruhi sering munculnya pengemis di Kota Gorontalo dan juga di tunjang oleh minimnya lapangan pekerjaan bagi mereka yang mempunyai latar belakang pendidikan yang rendah, karena banyak dari mereka yang tidak lulus sekolah bahkan tidak pernah sama sekali merasakan pendidikan di bangku sekolah. Berdasarkan hasil penelitian yang peneliti dapatkan dilapangan bahwa ada beberapa kasus tentang pengemis yang mengalami permasalah ekonomi diantaranya ada yang ingin menjadi pengemis karena menurut dia menjadi seorang pengemis bisa mendapatkan uang yang cukup banyak dalam satu malam ketimbang harus membuat usaha kecil-kecilan seperti usaha warung. Kemudian ada juga pengemis yang memberikan alasan bahwa menjadi seorang penegmis adalah satu-satunya pililhan buat beliau karena keterbatasan pendidikan yang dimiliki sehingga kesulitan untuk mencari pekerjaan.

b. Panti Rehabilitasi

Panti rehabilitasi adalah tempat yang digunakan untuk pemulihan/pembetulan seperti sediakala, pengembalian nama baik dan pambaharuan kembali. Di kota Gorontalo para penyandang masalah sosial khususnya para pengemis harusnya dibawa ke tempat tersebut supaya mendapat penanganan secara intensif sesuai dengan kegunaan yang dimiliki oleh panti rehabilitasi tersebut. Sayangnya di kota Gorontalo belum dibangun panti rehabilitasi yang berguna untuk menampung para pengemis sehingga itu menjadi salah satu kendala bagi aparat dinas sosial setempat dalam melakukan proses pembinaan kepada para pengemis.

Berdasarkan hasil wawancara yang peneliti dapatkan dilapangan bahwa panti rehabilitasi sangat beperan penting dalam hal melakukan program pembiaan pengemis karena panti rahabilitasi itu bisa menjadi tempat tinggal bagi para pengemis untuk mengitu proses pembinaan dengan maksimal. Tidak adanya panti rehabilitasi di Kota Gorontalo membuat proses pembinaan yang dilakukan oleh aparat dinas sosial tidak berjalan efektif walaupun mereka sudah menjalankan tugasnya dengan baik dengan tetap melakukan pembinaan walaupun hanya di kantor dinas sosial. Pemerintah harus segera membuat panti rehabilitasi di Kota Gorontalo agar jumlah pengemis tidak akan bertambah tiap tahunnya dan dapat diatasi secepatnya.

c. Regulasi 
Regulasi adalah suatu peraturan yang dibuat untuk membantu mengendalikan suatu kelompok, lembaga organisasi, dan masyarakat demi mencapai tujuan tertentu dalam kehidupan bersama, bermasyarakat, dan bersosialisasi. Tujuan dibuatnya regulasi adalah untuk mengendalikan manusia atau masyarakat dengan batasanbatasan tertentu. Salah satunya adalah pengemis, masalah pengemis ini memang perlu di atasi dengan dibuatnya regulasi agar aparat dinas sosial mampu dengan mudah mengatasi maraknya para pengemis yang ada di wilayah-wilayah tertentu khususnya Kota Gorontalo. Namun, berdasarkan hasil wawancara peneliti sebelumnya bersama Kepala bidang rehabilitasi sosial menyatakan bahwa belum adanya Perda khusus yang mengantur tentang pengemis membuat aparat dinas sosial kesulitan menangangi para pengemis. hal ini tentunya perlu ada perhatian dari pemerintah provinsi Gorontalo untuk membuat Perda khusus yang mengatur tentang pengemis agar proses pembinaan yang dilakukan oleh aparat dinas sosial Kota Gorontalo bisa berjalan dengan baik.

d. Kerja sama dengan instansi terkait

Kerja sama dengan instansi terkait seperti Satpol PP merupakan poin penting yang bisa dilakukan oleh aparat dinas sosial dalam hal melakukan program pembinaan pengemis dengan begitu Satpol PP yang akan bertugas untuk menertibkan para pengemis dan di antarkan ke kantor dinas sosial kemudian dilakukan pembinaan dikantor dinas sosial.

Berdasarkan hasil wawancara sebelumnya bahwa salah satu penghambat dari aparat dinas sosial dalam melakukan program pembinaan pengemis di Kota Gorontalo adalah tidak adanya kerja sama dengan instansi terkait. Hal inilah yang membuat pembinaan terhadap para pengemis itu tidak efektif. karena semua proses pembinaan dari mengumpulkan pengemis yang seharusnya jadi tugas Satpol PP justru hanya dilakukan langsung oleh aparat dinas sosial tanpa ada kontribusi dari pihak Satpol PP. hal ini menujukkan bahwa instansi terkait dan dinas sosial Kota Gorontalo terlihat tidak ada komunikasi dan semuanya dilimpahkan kepada dinas sosial Kota Gorontalo.

\section{KESIMPULAN}

Berdasarkan hasil penelitian atau riset dari pembahasan di atas bahwa Kinerja Aparat Dinas Sosial dalam melakukan pembinaan Pengemis di Kota Gorontalo itu sudah dilakukan secara bertahap yaitu setahun sekali oleh pemerintah dalam hal ini Dinas 
Sosial Kota Gorontalo. Namun, program pembinaan yang dilakukan belum bisa berjalan secara efektif dikarenakan adanya beberapa faktor yang menghambat Aparat Dinas Sosial dalam melakukan pembinaan pengemis di Kota Gorontalo.

Kinerja yang telah dicapai oleh Dinas Sosial dalam melakukan pembinaan pengemis dilakukan dengan beberapa usaha seperti memberikan dana usaha dengan mengikuti tahapan-tahapan dalam pembinaan seperti mengikuti bimbingan mental, bimbingan kesehatan, bimbingan ketertiban, dan bimbingan terhadap para pengemis Kota Gorontalo. Hal ini perlu juga ditingkatkan, agar para pengemis dapat merasakan kinerja atau usaha-usaha yang diberikan oleh pemerintah secara merata.

Namun ada pula faktor-faktor yang menjadi penghambat Kinerja Aparat Dinas Sosial Dalam Melakukan Pembinaan Pengemis di Kota Gorontalo. Salah satu faktor yang berpengaruh adalah belum adanya Peraturan Daerah (Perda) khusus mengenai pengemis, sehingga fasilitas-fasiltas pendukung seperti rumah singgah atau panti rehabilitasi belum ada. Kemudian hambatan lain yaitu tidak adanya kerja sama dengan instansi terkait seperti Satpol PP membuat proses pembinaan yang dilakukan oleh Aparat Dinas Sosial tidak berjalan efektif karena seharunya Satpol PP bertugas untuk melakukan penertiban pengemis dan Aparat Dinas Sosial yang melakukan pembinaan.

Untuk mencapai keberhasilan dalam program pembinaan pengemis di Kota Gorontalo, seharusnya Dinas Sosial menggandeng Pemerintah untuk bisa membuat suatu terobosan rancangan Perda (Peraturan Daerah) khusus mengenai pengemis agar fasilitas-fasilitas pendukung seperti, rumah singgah atau panti rehabilitasi bisa di bangun. Sehingga pembinaan bisa terlaksana secara maksimal.

\section{DAFTAR PUSTAKA}

Bastaman, Hanna P. 2000, Meraih hidup bermakna kisah pribadi dengan pengalaman tragis, Jakarta: paradigma

Dwidinanti Vol 3, No 1 (2016) Prosiding Penetian dan Pengabdian Kepada Masyarakat Jurnal Administrasi Publik Vol. 2 No. 1 (2017) oleh Khoiron

Muh.Sabar, 2015. Skripsi Kinerja dina sosial dalam pelaksanaan program pembinaan anak jalan di kota makassar 
Mulyadi, 2007. Akuntansi Biaya , Edisi ke 3. Yogyakarta: STIE YKPN. 63 Pasolong.Harbani. 2010. Teori Administrasi Publik, Bandung:Alfabeta

Peraturan Walikota Gorontalo Nomor 13 Tahun 2008

Sugiyono, metode penelitian pendidikan (pendekatan kualitatif, kuantitatif, dan R\&D), Bandung: Alfabeta, 2013 